\title{
SLOVENŠČINA V BENEŠKI SLOVENIJI IN VLOGA DVOJEZIČNE ŠOLE V ŠPETRU PRI MEDGENERACIJSKEM PRENOSU JEZIKA: STALIŠČA STARŠEV
}

\author{
Maja MEZGEC \\ Pedagoška fakulteta, Univerza na Primorskem in Slovenski raziskovalni \\ Inštitut SLORI
}

Mezgec, M. (2017): Slovenščina $v$ Beneški Sloveniji in vloga dvojezične šole v Špetru pri medgeneracijskem prenosu jezika: stališča staršev. Slovenščina 2.o, 5 (2): 1-32.

DOI: http://dx.doi.org/10.4312/slo2.0.2017.2.1-32.

Članek predstavlja prvi izsek raziskovalnega dela pri ciljnem raziskovalnem projektu Priložnosti in možnosti za ohranjanje oziroma revitalizacijo slovenščine med slovensko manjšinsko skupnostjo $v$ sosednjih državah, namenjenem preučevanju stanja slovenskega jezika v Beneški Sloveniji. V kontekstu globalizacijskih procesov, evropskih integracijskih procesov, ugodnejših in trdnejših zakonskih podlag (t. i. zaščitnega zakona) ter predvsem zaradi prisotnosti dvojezične šole lahko oblikujemo hipotezo, da $\mathrm{v}$ Beneški Sloveniji obstajajo ugodne okoliščine za jezikovno revitalizacijo in deasimilacijo mlajših generacij, kar vključuje tudi ponovno učenje slovenščine med generacijami, pri katerih je medgeneracijski prenos jezika zastal. Iz zbranih podatkov je mogoče izluščiti, da je v prejšnji generaciji medgeneracijski prenos jezika pogosto zastal z začetkom šolanja oz. vstopom v vrtec, ki je zaznamoval prehod na italijanski jezik. Tudi zato je dvojezično šolanje za Beneško Slovenijo pomemben dosežek, vendar samo po sebi še ni zadosten pogoj za ohranjanje ali oživitev medgeneracijskega prenosa jezika. Potrebni so še drugi ukrepi jezikovnega načrtovanja in jezikovne politike. Ob tem gre poudariti, da se ti procesi razvijajo $\mathrm{v}$ okolju, ki je bolj naklonjeno slovenščini in dvojezičnosti, kot je bilo v preteklosti.

Ključne besede: slovenska manjšina, dvojezično šolanje, deasimilacija, medgeneracijski prenos jezika 


\section{UVOD}

V članku izhajamo iz raziskovalnega dela, ki smo ga opravili pri ciljnem raziskovalnem projektu Priložnosti in možnosti za ohranjanje oziroma revitalizacijo slovenščine med slovensko manjšinsko skupnostjo $v$ sosednjih državah. ${ }^{1}$ Predstavljamo izsek, ki je namenjen Beneški Sloveniji. ${ }^{2}$ V kontekstu globalizacijskih procesov, evropskih integracijskih procesov, ugodnejših in trdnejših zakonskih podlag (t. i. zaščitnega zakona) ter predvsem zaradi prisotnosti dvojezične šole lahko oblikujemo hipotezo, da v Beneški Sloveniji obstajajo ugodne okoliščine za jezikovno revitalizacijo in deasimilacijo mlajših generacij, kar vključuje tudi ponovno učenje slovenščine med generacijami, pri katerih je medgeneracijski prenos jezika zastal.

V nadaljevanju predstavljamo prve izsledke raziskovalnega dela, ki je namenjen analizi medgeneracijskega prenosa slovenščine, motivov za vpis $\mathrm{v}$ dvojezično šolo in pričakovanj o dvojezičnem šolanju. Pri analizi smo uporabili kombinacijo kvantitativnih in kvalitativnih podatkov. Predhodno smo pregledali že zbrane podatke o Slovencih v Italiji s podatki po pokrajinah in ločeno za Špeter. Naredili smo torej presek raziskav in podatkov o Slovencih v Italiji in izpostavili samo podatke za Špeter. V empiričnem delu pa smo uporabili kvalitativne metode in izvedli intervjuje s starši otrok, ki so obiskovali dvojezično šolo v šolskem letu 2016/17.

\section{SLOVENSKA MANJŠINA V ITALIJI IN VPRAŠANJE JEZIKA}

Slovenci v Italiji so zgodovinsko naseljeni v deželi Furlaniji - Julijski krajini

\footnotetext{
${ }^{1}$ Pri izvedbi projekta sodelujejo: Inštitut za narodnostna vprašanja, Slovenski raziskovalni inštitut SLORI, Filozofska fakulteta Univerze v Ljubljani in Inštitut za slovenski jezik Frana Ramovša ZRC SAZU. Projekt financirajo Javna agencija za raziskovalno dejavnost Republike Slovenije, Urad Vlade Republike Slovenije za Slovence v zamejstvu in po svetu ter Ministrstvo za izobraževanje, znanost in šport Republike Slovenije.

2 Za slovensko poimenovanje mesta ali pokrajine Udine v Furlaniji sta v rabi dve različici; poleg tu uporabljene Videm je namreč razširjena in ustaljena tudi pokrajinska oblika Viden. Za Beneško Slovenijo se na lokalni ravni uporablja tudi poimenovanje Benečija. Videmska pokrajina se v nadaljevanju pojavlja z malo začetnico, ker gre za zemljepisno področje. Videmska pokrajina kot upravna enota je bila v letu 2017 ukinjena.
} 
vzdolž meje s Slovenijo. Naselitveni prostor slovenske manjšine se razprostira od Alp do Jadranskega morja in obsega predele tržaške, goriške in videmske pokrajine.

Pri analizi položaja in razvojnih perspektiv Slovencev v Italiji je vprašanje jezika ključnega pomena, saj jezik tu ne igra le vloge sredstva sporazumevanja, temveč deluje tudi kot najbolj razpoznaven in neposreden znak slovenske prisotnosti. Raziskave, ki obravnavajo Slovence v Italiji, jeziku večinoma pripisujejo pomembno vlogo pri ohranjanju narodne identitete in samozavesti (Bratina in Sussi 1988; Stranj 1992; Susič 1998; Jagodic, Kaučič Baša in Dapit 2016). Sodobnejše raziskave kažejo, da se ob nekdanjih trdnih identitetah danes vse pogosteje pojavljajo kompleksnejše oblike večplastnih identitet (Pertot 2007), ob katerih se poraja vprašanje, ali so še neizogibno povezane z znanjem in rabo manjšinskega jezika, $\mathrm{z}$ njegovo aktivno rabo $\mathrm{v}$ vsakdanjem življenju ali $\mathrm{z}$ vključevanjem v slovensko družbeno-kulturno okolje. Tudi v pričujoči raziskavi smo zasledili primere posameznikov, ki se identificirajo tudi kot Slovenci, pa čeprav ne obvladajo slovenskega jezika oz. ga do določene mere obvladajo samo v pasivni obliki.

Za slovenski jezik na ozemlju Furlanije - Julijske krajine je značilno, da živi v tesnem stiku z italijanščino (na nekaterih območjih videmske in goriške pokrajine tudi s furlanščino, v Kanalski dolini pa še z nemščino), se z njo prekriva tako v narečjih kot $\mathrm{v}$ knjižnih zvrsteh, na tak način pa bistveno prispeva $\mathrm{k}$ oblikovanju svojevrstne regionalne jezikovne pokrajine. Zaradi vsakodnevnega stika $\mathrm{z}$ romanskim svetom in tudi zaradi drugih dejavnikov, npr. geografske obrobnosti, predvsem pa zaradi specifične politične zgodovine in prisotnosti državnih meja, ki so dalj časa ovirale stike med Slovenci z obeh strani obmejnega prostora, je slovenski jezik v Italiji v primerjavi s slovenskim jezikom v matični Sloveniji sčasoma razvil nekatere samosvoje poteze. Posebnosti se ne kažejo samo v narečjih in regionalnih različicah pogovornega jezika, ampak v manjši meri tudi $\mathrm{v}$ besedišču in glasoslovju standardne slovenščine (Jagodic, Kaučič Baša in Dapit 2016: 68). Jezikovne razmere med 
Slovenci na Tržaškem in Goriškem se močno razlikujejo od razmer med Slovenci v Beneški Sloveniji, čeprav jih povezujeta skupni etnični izvor in upravno-politično telo: dežela Furlanija - Julijska krajina in država Italija. Razlike med posameznimi deli manjšine so zgodovinsko pogojene, saj so posamezna območja slovenske naselitve $\mathrm{v}$ preteklosti pripadala različnim političnim tvorbam (Jagodic, Kaučič Baša in Dapit 2016: 69).

\subsection{Pravni okvir}

Prehod iz 20. v 21. stoletje so zaznamovale pomembne novosti na področju pravne zaščite slovenske narodne skupnosti v Italiji. Leta 2001 je bil sprejet državni zakon za globalno zaščito slovenske narodne skupnosti št. 38, leta 2007 pa so bile z deželnim zakonom Avtonomne dežele Furlanije - Julijske krajine št. 26 sprejete vsebine državnega zakona. Obenem velja omeniti okvirni državni zakon št. 482/1999 za zaščito zgodovinskih jezikovnih manjšin v Italiji. Oba navedena zakona urejata temeljne pravice slovenske narodne skupnosti v Italiji v skladu s 6. členom italijanske ustave, ki uvaja načelo zaščite jezikovnih manjšin, in z evropsko ter mednarodno zakonodajo za to področje. Ta pravni okvir zagotavlja narodni skupnosti kulturno avtonomijo, ki je osredinjena predvsem na javno rabo slovenskega jezika, na model izobraževalnega sistema tako s slovenskim učnim jezikom kot dvojezični model in na avtonomno organizacijsko strukturo na kulturnem in gospodarskem področju, kar so temeljni dejavniki za ohranjanje in razvoj manjšinske skupnosti (Vidau 2016).

Izvajanje zaščitnih določil ni ne samodejno ne takojšnje: obstajajo politični, birokratski in družbeno-ekonomski dejavniki, ki ovirajo izvajanje veljavnih zakonskih določil. Del politike in javnega mnenja ostaja namreč vpet v klasično vizijo nacionalne enojezične in monokulturne države. Zaradi tega dojemajo jezikovne in kulturne razlike, ki izvirajo iz prisotnosti neke zgodovinske manjšine, kot folkloristične ostanke neuspelega procesa asimilacije $\mathrm{z}$ večinsko kulturo (prav tam).

Dodatna težava pri izvajanju veljavne zakonodaje je v tem, da je za udejanjanje 
zakonskih določb treba sprejeti tudi zadevne izvedbene pravilnike in odloke. Njihova odobritev pa je običajno vezana na počasne birokratske postopke javne uprave, ki lahko tako postanejo politično orodje za oviranje zaščite (Vidau 2016).

\subsection{Jezikovni položaj Slovencev v Benečiji}

Slovenci v videmski pokrajini naseljujejo skrajni zahodni rob avtohtonega poselitvenega ozemlja. Za območje Karnajske in Terske ter Nadiških dolin se uporablja tudi izraz Beneška Slovenija oz. Benečija.

Z jezikovnega vidika lahko trdimo, da predstavljajo Slovenci v Beneški Sloveniji najšibkejši člen slovenske manjšine $\mathrm{v}$ Italiji, kar je posledica zgodovinskih dejstev in političnih razmer. Slovenci iz današnje tržaške in goriške pokrajine ter iz Kanalske doline na skrajnem severovzhodu videmske pokrajine so do konca prve svetovne vojne delili politično usodo s preostalimi deli slovenskega naroda znotraj Avstro-Ogrske, medtem ko je bilo slovensko govoreče prebivalstvo Beneške Slovenije in Rezije stoletja pod oblastjo Beneške republike, leta 1866 pa se je priključilo Italiji. Ta zgodovinska dejstva so določala tudi položaj slovenščine na posameznih območjih. Na Tržaškem, Goriškem in v Kanalski dolini je bila slovenščina do razpada Avstro-Ogrske leta 1919 uradni jezik (na Tržaškem in Goriškem poleg nemščine in italijanščine, v Kanalski dolini poleg nemščine) in učni jezik v osnovnih šolah. V Beneški Sloveniji in v Reziji italijanska oblast ni omogočila nobene oblike javne rabe slovenščine, v šole ni uvedla slovenskega pouka, takoj po priključitvi leta 1866 pa je poitalijančila zemljepisna imena. Tudi po drugi svetovni vojni je država vzdrževala zgodovinsko pogojene razlike med deli manjšine v posameznih pokrajinah in Slovencev na Videmskem vse do uveljavitve zakona o varstvu slovenske manjšine v Furlaniji - Julijski krajini (Zakon 38/2001) niti formalno ni obravnavala kot Slovence, temveč samo kot »državljane slovanskega izvora « (Jagodic, Kaučič Baša in Dapit 2016: 69).

$\mathrm{Z}$ vidika položaja jezika $\mathrm{v}$ javnosti je podoba slovenskega jezika $\mathrm{v}$ Beneški 
Sloveniji dokaj enotna, saj se kot celota razlikuje od stanja v goriški in tržaški pokrajini, kjer je prisotnost jezika v družbi bistveno večja, zlasti na področju šolstva. V Beneški Sloveniji doseže slovenski jezik najvišji status navadno v sožitju z italijanščino oz. v obliki dvo- ali večjezičnosti. Na tem kriteriju temelji tudi zasnova dvojezične špetrske osnovne šole, ki je edina državna šolska ustanova $\mathrm{s}$ poukom $\mathrm{v}$ slovenskem in italijanskem jeziku $\mathrm{v}$ vsej pokrajini (Jagodic, Kaučič Baša in Dapit 2016: 80). Iz podatkov o jezikovni krajini (Mezgec 2015) lahko razberemo, da je v Beneški Sloveniji jezikovna krajina večinoma enojezična $(87,4$ \% napisov je enojezičnih, večinoma gre za napise v italijanščini) in le 5,3 \% napisov je tudi v slovenskem jeziku. Nimamo pa relevantnih popisov, ki bi odražali realno sliko jezika kot vsakdanje sporazumevalne prakse (Grgič 2017) in niti o dejanski sporazumevalni zmožnosti v slovenščini, kot jih imamo za primer Kanalske Doline (Gliha Komac 2009).

V Beneški Sloveniji je uporaba narečnih različic posebno izrazita, kar je delno povezano tudi s pomanjkanjem možnosti za šolanje v slovenščini pri prejšnjih generacijah. Slovenski standardni jezik se uporablja samo v izobraževalne namene, v drugih govornih položajih pa prevladuje uporaba narečja. Uvedba standardne slovenščine v izobraževalne namene ni bila za lokalno prebivalstvo samo po sebi umevna. V nadaljevanju uporabljamo pri opisu raziskovalnega dela termin slovenščina in slovenski jezik za obe zvrsti, razen kjer se narečje izrecno omenja. Slovenščino in narečje upoštevamo kot kontinuum, saj namen prispevka ni analiza odnosa med narečjem in slovenščino, ampak ugotavljanje medgeneracijskega prenosa jezika, pa naj gre za standardni jezik ali za slovensko narečje. Čeprav glede na dejstvo, da starejše generacije niso imele na voljo nobene oblike šolanja $\mathrm{v}$ slovenščini, opažamo, da gre pri medgeneracijskem prenosu jezika v glavnem za prenos narečja.

3 SLOVENSKI JEZIK V VZGOJNO IZOBRAŽEVALNEM PROCESU V 


\section{BENEČIJ I}

\subsection{Slovenska šola v Italiji in dvojezična šola v Špetru}

V nadaljevanju podajamo ključne informacije za razumevanje dvojezičnega šolanja v Beneški Sloveniji. Poglavje nima namena nuditi celotnega vpogleda v sistem šolanja v slovenskem jeziku niti v sistem dvojezičnega šolanja v Benečiji ali v njegov zgodovinski razvoj.

Za jezikovne manjšine je pravica do učenja maternega jezika in pravica do učenja v maternem jeziku ključna za ohranjanje jezika in prenašanje znanja jezika ter kulturne dediščine iz generacije v generacijo. Šolanje v manjšinskem jeziku je bilo vedno ena izmed osnovnih zahtev manjšine; možnosti za šolanje v materinščini kažejo tudi stopnjo zaščite, ki jo večina dodeljuje manjšini (Mezgec 2004).

Šola je ena ključnih družbenih institucij, v manjšinski skupnosti pa pridobi šola z manjšinskim učnim jezikom še dodaten pomen in poslanstvo. Med njene vzgojno-izobraževalne cilje sodi tudi ohranjanje jezikovnih in kulturnih značilnosti skupnosti ter medgeneracijsko prenašanje njene kulturne dediščine. S tega vidika je izobraževanje v materinščini temeljnega pomena za obstoj in razvoj manjšinske družbe (Bogatec 2015b: 6). Šola predstavlja pomemben socializacijski dejavnik, kajti šolajoča se populacija preživi v vzgojno-izobraževalnih ustanovah večji del dneva, zato ima lahko to okolje pomembne učinke tudi z jezikovnega vidika. Pomeni torej ključno priložnost za izpostavljenost določenemu jeziku ali jezikom.

Šole s slovenskim učnim jezikom in dvojezična šola v Špetru sodijo v sistem italijanskih državnih šol. Kot sestavni del italijanskega izobraževalnega sistema so vpletene v razvojni proces državnega šolstva, kot manjšinske ustanove pa se soočajo s specifičnimi vprašanji izobraževanja v manjšinskem jeziku (Bogatec 2016b). Delujejo po načelih in pravilih, ki veljajo za italijanske državne šole. Šolske programe odobri ministrstvo in so povsem enaki kot programi 
italijanskih šol $\mathrm{z}$ dodatnim predmetom Slovenski jezik in literatura ter nekaterimi vsebinskimi dodatki pri zgodovini in zemljepisu (Bogatec 2016b).

Dvojezična večstopenjska šola v Špetru predstavlja edino stvarnost v Beneški Sloveniji in na Videmskem, v kateri je slovenščina prisotna kot učni jezik. Pod njenim okriljem deluje dvojezični otroški vrtec (starost otrok 3-5 let), dvojezična osnovna šola (starost otrok 6-10 let) in dvojezična srednja šola prve stopnje (starost otrok 11-13 let). Šola je nastala v osemdesetih letih: vrtec v šolskem letu 1984/85, osnovna šola v letu 1986/87 in nazadnje še srednja šola prve stopnje v letu 2007/08. V začetku je delovala kot zasebna šola, vendar je z zaščitnim zakonom iz leta 2001 postala polnopravna državna šola. Drugih možnih oblik šolanja v slovenskem jeziku v Beneški Sloveniji ni: ne šolanja izključno v slovenskem učnem jeziku (kot npr. na Tržaškem in Goriškem) ne učenja slovenščine kot drugega/tujega jezika (kot v nekaterih italijanskih šolah na Tržaškem).

V dvojezični šoli v Špetru sta italijanščina in slovenščina enakovredna učna jezika po didaktičnem modelu ena oseba - en jezik. V celodnevni osnovni šoli se učno snov posameznih predmetov podaja v obeh jezikih, na srednji šoli prve stopnje pa potekajo učne ure nekaterih predmetov v slovenščini, drugih pa v italijanščini (Bogatec 2016b).

Ustanovitev dvojezične šole je narekovalo predvsem spoznanje, da so silnice, ki vodijo v vse večji obseg komunikacije v italijanščini in torej opuščanje slovenščine kot sporazumevalnega jezika, tako močne, da ni bilo več mogoče računati le na za Benečijo tradicionalne oblike ohranjanja slovenskega narečja (družina, vaško življenje). Vpliv množičnih občil, izpraznjenje vasi in vse manjše socializacijske možnosti v njihovih okvirih ob hkratni večji družbeni mobilnosti in vsakodnevni izpostavljenosti drugojezičnemu okolju, vključevanje otrok v italijanski vzgojnoizobraževalni proces v najzgodnejših letih - vse to je privedlo do skrajne redukcije v prenašanju slovenskega narečja na mlajše generacije. Pobude, ki so posegale zgolj v prosti čas otrok, so se v takem položaju pokazale kot nezadostne in neučinkovite. Po drugi strani pa je šlo za to, da se ugled slovenščine, potisnjene na rob družbenega dogajanja, dvigne /.../ . Od tod torej uporaba slovenščine v šoli, ki postane tako 
posrednik novih spoznanj in nosilec različnih dejavnosti, obenem pa se lahko razvija tudi na višjih izraznih ravneh, ki jih omogoča obvladovanje knjižnega jezika (Gruden 1997: 39).

V Beneški Sloveniji se možnost dvojezičnega šolanja zaključi po srednji šoli prve stopnje (14. letu starosti). Posameznikom so v okolici na voljo le srednje šole druge stopnje z italijanskim učnim jezikom. Pomanjkanje pouka v slovenščini na višjih stopnjah pomeni za slovensko narodno skupnost v Beneški Sloveniji velik primanjkljaj. $\mathrm{Z}$ vidika razvoja in utrditve jezikovnih kompetenc je kontinuiteta rabe jezika ključna. V trenutku, ko učenec zaključi dvojezično šolanje in se vključi v šole z (izključno) italijanskim učnim jezikom, je naloga in skrb družine ter drugih ustanov in organizacij, da ohranjajo in dograjujejo njegovo vez s slovenskim jezikom. Ta vez se namreč lahko okrepi, lahko pa se tudi prekine. Veliko je sicer odvisno od življenjskih izkušenj in izbir posameznika ter družine, vendar je pomembno tudi, kakšne vrste dejavnosti razvijajo slovenske ustanove in organizacije na tem območju in komu so te vsebine namenjene (Bogatec 2012a).

\subsection{Populacija dvojezične šole v Špetru}

Za opis populacije dvojezične šole v Špetru smo opravili izbor kvantitativnih podatkov, s katerimi SLORI že razpolaga, tako da smo izluščili podatke za Špeter.

Analize o šolajoči se populaciji nudijo koristen vpogled v strukturo slovenske narodne skupnosti v Italiji (Strajn 1992; Bogatec 2015a). Ker v italijanskih popisih ni podatka o narodnostni in jezikovni sestavi prebivalstva, raziskovalci dejansko ne razpolagamo s podatki o številčnem obsegu manjšinske skupnosti ter njeni narodnostni in jezikovni sestavi. S spremljanjem sprememb pri številu vpisanih na posamezne stopnje šolanja lahko spoznamo, kako se spreminja potencialni krog govorcev slovenskega jezika in poznavalcev slovenske kulture v Italiji. Popis šolajočega se prebivalstva nam nudi informacije o slovenskem 
jedru in tudi o t. i. mejnih, sivih conah (Bogatec 2015a: 6).

V Špetru je bil porast vpisa v dvojezično večstopenjsko šolo opazen vse do leta 2003, ko se je ta trend nekoliko upočasnil. V obdobju 2002/03-2016/17 se je v skupnem seštevku populacija vpisanih na vseh stopnjah v Špetru povečala za 49 \% (Bogatec 2016a). V šolskem letu 2016/17 večstopenjska šola izkazuje rekorden vpis: 282 otrok (Bogatec 2016a) (Slika 1, Tabela 1).

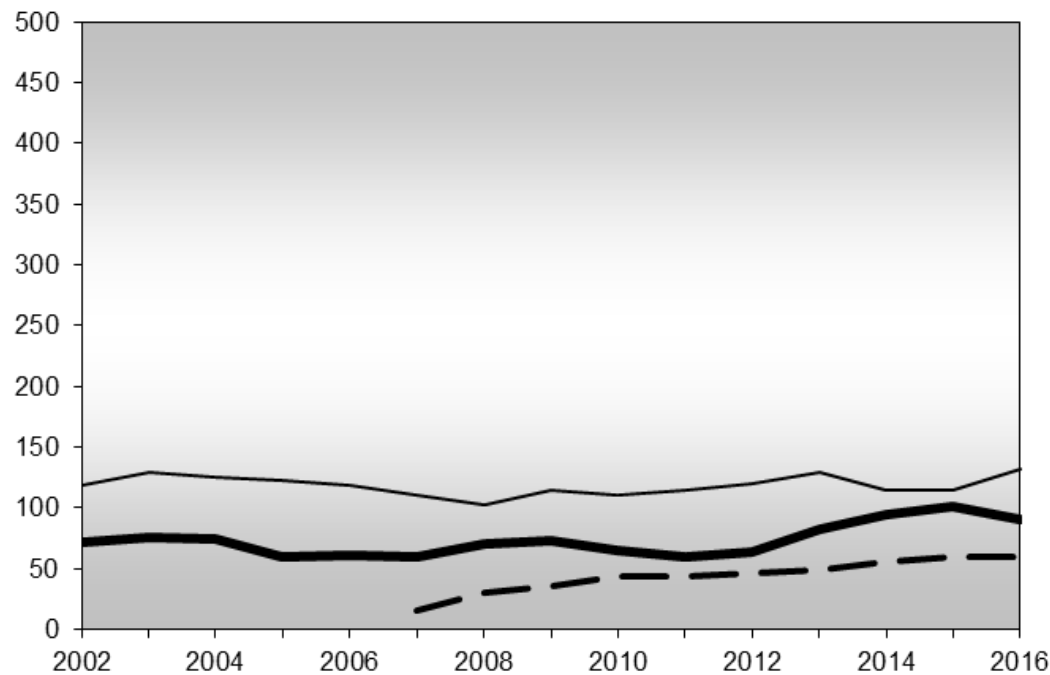

Slika 1: Dvojezična šola v Špetru: dinamika vpisov učencev v obdobju 2002-2015.* (Vir: Bogatec 2016a.)

* Pomen črt: tanka črta = osnovna šola; okrepljena črta = vrtec, črtkana črta = srednja šola prve stopnje. 


\begin{tabular}{|c|c|c|c|c|c|c|c|c|c|c|c|c|c|c|c|c|}
\hline & \multicolumn{2}{|c|}{$2009 / 10$} & \multicolumn{2}{|c|}{ 2010/11 } & \multicolumn{2}{|c|}{ 2011/12 } & \multicolumn{2}{|c|}{ 2012/13 } & \multicolumn{2}{|c|}{$2013 / 14$} & \multicolumn{2}{|c|}{$2014 / 15$} & \multicolumn{2}{|c|}{ 2015/16 } & \multicolumn{2}{|c|}{ 2016/17 } \\
\hline & $1 r^{* *}$ & skupaj & $1 \mathrm{r}$ & skupaj & $1 \mathrm{r}$ & skupaj & $1 \mathrm{r}$ & skupaj & $1 \mathrm{r}$ & skupaj & $1 \mathrm{r}$ & skupaj & $1 \mathrm{r}$ & skupaj & $1 \mathrm{r}$ & skupaj \\
\hline Vrtec & 23 & 73 & 18 & 65 & 15 & 60 & 25 & 63 & 35 & 83 & 34 & 95 & 27 & 101 & 25 & 91 \\
\hline $\begin{array}{l}\text { Osnovna } \\
\text { šola }\end{array}$ & 28 & 114 & 25 & 111 & 25 & 114 & 24 & 120 & 30 & 129 & 19 & 115 & 24 & 115 & 36 & 132 \\
\hline $\begin{array}{l}\text { Srednja } \\
\text { šola }\end{array}$ & 10 & 36 & 19 & 43 & 18 & 44 & 15 & 46 & 18 & 49 & 22 & 55 & 20 & 59 & 18 & 59 \\
\hline skupaj & 61 & 223 & 62 & 219 & 58 & 218 & 64 & 229 & 83 & 261 & 75 & 265 & 71 & 275 & 79 & 282 \\
\hline
\end{tabular}

Tabela 1: Dvojezična osnovna in srednja šola ter vrtec v Špetru: vpis učencev po številu v obdobju 2009/10-2016/17. (Vir: Bogatec 2016a; arhiv SLORI-ja.)

$* *$ r $=$ prvi razred. 
Analiza narodnostnih in jezikovnih značilnosti šolajoče se populacije 3 tudi v Špetru, kot to tudi sicer velja za tržaško in goriško pokrajino, kaže naraščanje zanimanja neslovenskih družin za vpis otrok v slovensko šolo.

Podatki o narodnosti učencev, 4 vpisanih v prve letnike posamezne stopnje šolanja v šolskem letu 2014/15, kažejo, da v Špetru skoraj tri četrtine učencev (74 \%) izhajajo iz neslovenskih zakonov, 24 \% iz mešanih in 3 \% iz slovenskih zakonov (Bogatec 2011a) (Tabela 2).

\begin{tabular}{|c|c|c|c|}
\hline Šolsko leto & Slovenski zakon & Mešani zakon & Neslovenski zakon \\
\hline $2010 / 11$ & $4 \%$ & $29 \%$ & $67 \%$ \\
\hline $2011 / 12$ & $6 \%$ & $19 \%$ & $74 \%$ \\
\hline $2014 / 15$ & $3 \%$ & $24 \%$ & $74 \%$ \\
\hline
\end{tabular}

Tabela 2: Dvojezična šola v Špetru: narodnost učencev, vpisanih v prvi letnik v letih 2010/11, 2011/12 in 2014/15.

(Vir: Bogatec 2011a in 2016a.)

Pojav je verjetno posledica dolgotrajnih procesov evropske integracije, zlasti po vstopu Republike Slovenije v EU, normalizacije odnosov med večino in manjšino ter ozaveščanja prebivalstva o prednostih večjezičnosti. Naraščanje zanimanja za slovensko kulturo in jezik pri neslovenskih družinah in posledično večanje števila

${ }^{3}$ Projekt o spremljanju narodnostnih in jezikovnih značilnosti šolajoče se populacije je oblikoval SLORI v sodelovanju z ravnateljstvi slovenskih vrtcev ter šol v tržaški in goriški pokrajini ter $\mathrm{z}$ večstopenjsko šolo $\mathrm{s}$ slovensko-italijanskim dvojezičnim poukom $\mathrm{v}$ Śpetru. Gre za podatke o vpisih v prve letnike šol s slovenskim učnim jezikom in dvojezične šole v Špetru. Na anketno polo so v vrtcih, osnovnih in srednjih šolah prve stopnje odgovarjali starši, na srednjih šolah druge stopnje pa dijaki (Bogatec 2015a). Tovrstno zbiranje podatkov se je začelo v šolskem letu 2010/11 in nadaljevalo vse do leta 2014/15. Pri nekaterih izvedbah so bili dodani še sklopi tematskih vprašanj.

4 Podatki o narodnosti se nanašajo na narodnostni izvor posameznika: izražajo narodnostno strukturo $\mathrm{v}$ zakonu staršev oz. kombinacijo narodnosti očeta in matere. Narodnostni izvor samodejno ne določa tudi otrokove narodne pripadnosti. 
govorcev slovenskega jezika in poznavalcev slovenske kulture predstavljata nedvomno velik izziv. Spremembe v narodnostni in jezikovni sestavi šolajoče se populacije pa postavljajo pod vprašaj vlogo slovenske šole /in dvojezične šole $\mathrm{v}$ Beneški Sloveniji, op. a./ pri ohranjanju in utrjevanju narodne zavesti in jo silijo $\mathrm{k}$ obravnavi vprašanja narodne identitete s sodobnejšimi pristopi (Bogatec 2015a: 10).

Zanimiva je tudi primerjava podatkov dveh generacij, ki kaže, da so mešani zakoni bolj ranljivi in v večji meri izpostavljeni asimilaciji: v mešanih zakonih je naslednja generacija pogosteje prešla v italijanski zakon. V starejši generaciji je bilo 33 \% mešanih zakonov, v naslednji generaciji pa 20 \%. Naraslo pa je število italijanskih zakonov (s 46 \% na $61 \%$ ), medtem ko pri ostalih kategorijah ni opaziti večjih prehodov po narodnosti med generacijama (Tabela 4).

\begin{tabular}{l|r|r|r|r}
\hline & Slovenska & Mešana & \multicolumn{1}{l|}{ Italijanska } & \multicolumn{1}{l}{ Druga } \\
\hline $\begin{array}{l}\text { Narodnostni izvor } \\
\text { otroka (glede na } \\
\text { narodnost staršev) }\end{array}$ & $6 \%$ & $20 \%$ & $61 \%$ & $12 \%$ \\
\hline $\begin{array}{l}\text { Narodnostni izvor } \\
\text { staršev (glede na } \\
\text { narodnost starih } \\
\text { staršev) }\end{array}$ & $6 \%$ & $33 \%$ & $45 \%$ & $16 \%$ \\
\hline
\end{tabular}

Tabela 4: Dvojezična šola v Špetru: narodnostni izvor učencev glede na narodnostni izvor staršev in starih staršev. (Vir: Bogatec 2012b.)

Zanimiv trend se kaže tudi pri rabi jezika. Podatki, zbrani leta 2014 v raziskavi Šola, družina in zunajšolske dejavnosti (Maver 2015), kažejo, da 3 \% učencev v Špetru5 kot pogovorni jezik v družini uporabljajo slovenščino, 40 \% jih uporablja slovenščino in drug jezik, 57 \% pa neslovenski jezik, pretežno

$5 \mathrm{~V}$ raziskavi so bili zajeti razredi od 3. do vključno 8. oz. po italijanskem sistemu od 3. razreda do konca srednje šole prve stopnje. 
italijanščino $(N$ = 112). Podatki o pogovornem jeziku v širšem domačem okolju (ki vključuje tudi pogovorni jezik s starimi starši) ostajajo pri slovenščini nespremenjeni (3\%), povečuje pa se odstotek kombinirane rabe slovenščine in italijanščine (57 \%). Posledično je odstotek rabe italijanščine kot pogovornega jezika nižji (40 \%). Podatek nakazuje, da je pri starejši generaciji - pri starih starših - slovenščina prisotna v večji meri, saj se stari starši pogovarjajo v slovenščini. Zasledimo torej primere mešanih družin, pri katerih je medgeneracijski prenos jezika zastal. Razvidno pa je tudi, da so se starši, ki niso bili deležni medgeneracijskega prenosa slovenščine, odločili za dvojezično šolanje zaradi želje po oživitvi slovenščine in ponovnem uvajanju slovenščine v vsakdan prihodnjih rodov.

Do podobnih ugotovitev je prišla tudi Zuljan Kumar (2016), ki za videmsko pokrajino navaja, da lahko v mnogih družinah otroci slovensko oz. furlansko govorijo samo s svojimi starimi starši, ker ti svojih otrok niso naučili slovenščine. Vendar se kljub temu pripadniki srednje generacije počutijo Slovence oz. Furlane ter svoje otroke spodbujajo k učenju in rabi slovenskega jezika (Zuljan Kumar 2016: 14).

Tudi podatki o rabi slovenščine v izvenšolskih govornih položajih jasno kažejo na obrobnost slovenskega jezika in njegov položaj v družbi. Le 4 \% učencev kot pogovorni jezik izven šole uporabljajo slovenščino, prav tako 4 \% slovenski in italijanski jezik, 83 \% jih uporablja italijanski, 4 \% italijanski in drug jezik, $6 \%$ pa samo drug jezik (Bogatec 2012a).

Starši v Špetru so o izbiri vrtca ali šole z dvojezičnim poukom v primerjavi s Tržaško in Goriško v večji meri izpostavili pomen učenja ter spoznavanja dveh jezikov in kultur (93 \% pritrdilnih odgovorov) ter kakovost vzgojnih in učnih dejavnosti (59 \%). Manjšo težo pa imata v primerjavi z rezultati ostalih dveh pokrajin slovenski izvor družine (25 \%) in slovenska narodnost staršev (6 \%) (Bogatec 2015a). 
4 IZBIRA SLOVENŠC̆INE IN DVOJEZIČNE ŠOLE: STALIŠČA STARŠEV

\subsection{Raziskovalna metoda}

Pri raziskovanju smo uporabili deskriptivno metodo. Podatke smo zbrali in obdelali s kvalitativnimi metodami. Za zbiranje podatkov smo uporabili globinske intervjuje. Z globinskimi intervjuji skušamo prodreti globlje v proučevanje raziskovalnih problemov in podrobneje posegamo $\mathrm{v}$ opise ter pojasnila, razlage, primerjave raznih dejanj, dogodkov, pojavov, ljudi in drugega iz vpraševančevih izkušenj in doživetij (Vogrinc 2008: 109). Intervjuji so bili posredni, individualni in anonimni. Respondente smo evidentirali ob pomoči vodstva šole. Z njimi smo stopili v stik v drugem semestru šolskega leta 2016/17 in jih z dopisom povabili k sodelovanju v raziskavi. S posamezniki, ki so se strinjali s sodelovanjem, smo se dogovorili za enkratni individualni intervju. Predvsem so nas zanimali posamezniki, ki imajo slovenske korenine, vendar je v prejšnjih generacijah prišlo do prekinitve $\mathrm{v}$ medgeneracijskem prenosu slovenskega jezika, in/ali posamezniki, ki želijo, da se njihovi otroci znova naučijo slovenščino, in so se zato odločili za vpis v dvojezično šolo. V intervjujih je pogovor stekel o govornih navadah $\mathrm{v}$ izvorni in sekundarni družini, stališčih do jezika (in narečja), motivih za vpis v dvojezično šolo, pričakovanjih glede dvojezičnega šolanja, pričakovanjih glede rabe slovenščine po zaključenem dvojezičnem šolanju, rabi slovenščine izven šolskega okolja, stikih s Slovenijo in Slovenci v Republiki Sloveniji. Intervjuji so potekali v namenski sobi muzeja v Špetru v maju in juniju 2017. Posamezniki so lahko izbirali med slovenskim in italijanskim pogovornim jezikom oz. narečjem. Intervjuje smo snemali, prepisali, uredili zbrano gradivo in opravili vsebinsko analizo.

V nadaljevanju navajamo izseke odgovorov v ležečem tisku. Zapisi so dobesedni in označeni s šifro respondenta. Raziskovalci nismo posegali v dobeseden prepis pogovora. Ker je večina pogovorov potekala v italijanskem jeziku, sledi v 
oklepaju slovenski prevod. ${ }^{6}$

\subsection{Ugotovitve}

Šola oz. možnost obiskovanja dvojezične šole je eden ključnih dejavnikov, ki prispeva k medgeneracijskemu prenosu jezika. Prejšnje generacije, vključno z generacijo staršev otrok, ki obiskujejo dvojezično šolo, niso imele možnosti dvojezičnega šolanja. Slovenščina takrat v šolstvu sploh ni bila prisotna. Danes z grenkobo gledajo na dejstvo, da je bila njihova generacija prikrajšana za to možnost. Za te starše je možnost dvojezičnega šolanja otrok neka oblika medgeneracijskega dosežka in izziva: zdajšnja generacija otrok ima to pravico, ki je sami niso imeli.

216: Alla mia generazione ci hanno tolto una grandissima opportunità: una cosa che ha rovinato la nostra identità. (Moji generaciji so odvzeli veliko priložnost: nekaj, kar je pokvarilo našo identiteto.)

215: Punto debole: non c'era scolarizzazione /in sloveno, op.au./ (Šibka točka: ni bilo šolanja /v slovenščini, op. a./.)

223: Io purtroppo faccio parte di quella generazione sfigata che ha avuto la scolarizzazione solo in italiano, però nel momento in cui ho finito le medie, poi di fatto si è aperta la bilingue. Se io fossi nata qualche anno dopo, ma io, /.../ e tanti di noi siamo stati penalizzati in questo senso. Per cui io ho questa cosa non la mando giù. Poi è difficile da autodidatta imparare una lingua. (Žal spadam $v$ nesrečno generacijo, ki se je šolala izključno $v$ italijanščini. Ravno ko sem zaključila osnovnošolsko izobraževanje, so dejansko ustanovili še dvojezično šolo. Ko bi se le rodila nekaj let kasneje, toda jaz /.../ in veliko nas je bilo prikrajšanih $v$ tem smislu. Zato tega ne morem preboleti. Kot samouk pa se s težavo naučiš jezika.)

Poleg tega, da slovenščina takrat ni bila prisotna $\mathrm{v}$ šolstvu, tudi okolje ni

6 Prevod: Jasmin Franza 
podpiralo in spodbujalo rabe slovenščine v družini. Prej obratno: učno osebje je priporočalo enojezičnost in domačo rabo italijanskega jezika. To priporočilo je bilo osnovano na ideoloških prepričanjih, nastrojenih proti slovenščini, in na prepričanju, da zgodnja dvojezičnost (in posledično izpostavljenost manjšinskim jezikom) ni priporočljiva, ker zavira otrokovo usvajanje glavnega - uradnega jezika - italijanščine. Tako so se pod pritiskom učnega osebja z obiskovanjem vrtca oz. šole pogosto spreminjale govorne navade v družinah: navadno v smeri, da so starši med sabo še vsaj delno ohranili slovensko narečje kot pogovorni jezik, z otroki pa so uporabljali italijanski jezik. Spremembe v pogovornem kodu so zajele tudi generacijo starih staršev, ki so se pogosto znašli v kočljivem položaju, saj so italijanski jezik slabo obvladali. Nekateri so se odločili za prehod k italijanščini, drugi pa so ohranili slovensko narečje kot govorni kod z mlajšo generacijo.

215: A casa si parlava il dialetto, anch'io lo parlavo da piccola, poi con la scolarizzazione è cambiato. Poi tutto in italiano. Gli adulti parlavano in dialetto e noi rispondevamo in italiano. (Doma smo uporabljali narečje, tudi sama sem ga govorila $v$ mladih letih, nato pa se je s šlanjem vse spremenilo. Potem je bilo vse v italijanščini. Odrasli so govorili v narečju, mi pa smo jim odgovarjali $v$ italijanščini.)

216: Mogoče v vrtcu so začeli govoriti italijanščino /z mano, op. a./, ker so učiteljice tako hotele. Doma pa vedno po narečju.

218: Ma, $v$ šoli se ni smelo govorit po slovensko.

222: non insegnamo lo sloveno, perchè dopo fan confusione. Che all'epoca non si sapeva, invece gli studi oggi dicono altro. (ne učimo jih slovenščine, ker bi jih spravilo $v$ zmedo. Takrat niso vedeli, medtem ko sodobne raziskave pravijo drugače.)

213: Ma, moji starši so bili bolj mladi in so gledali bolj daleč. Smo govorili narečje doma. /.../ Učiteljice so se priporočale, naj ne govorijo po narečje z nami, ker tako se ne naučimo italijanščine. Tako so potem starši govorili oboje 
/.../. Šele pri 20. sem prešla na slovenščino. /.../ Do vrtca samo po narečje, potem s šolo je menjalo.

Da se danes starši odločajo za slovenščino in dvojezično šolo, gre pripisati pomembnim spremembam oz. premikom na dveh področjih, in sicer v odnosu do slovenščine in $\mathrm{v}$ odnosu do zgodnje dvojezičnosti. V videmski pokrajini je bila slovenščina dolgo $\mathrm{v}$ neugodnem položaju. Danes pa starši občutijo spremembe v smeri odpiranja in sprejemanja slovenščine.

218: A noi è mancato il sostegno delle strutture che c'è adesso. Noi siamo in quella fase in cui lo sloveno era ghettizzato, emarginato, non era considerato. /.../ però so che a contatto con il circondario friulano, il mondo slavo era considerato in un certo modo un po' negativo. Anche all'interno della comunità sappiamo ben le tensioni che c'erano, veniva emarginato, veniva. Alcuni di noi l'hanno vissuto come una cosa quasi da nascondere, un aspetto che ti sminuiva. (Mi nismo imeli podpore ustanov, ki so dandanes prisotne. Smo iz tistega obdobja, ko je bila slovenščina potisnjena na rob, so se je izogibali, je niso upoštevali. /.../ Vem, da je furlanska okolica na nek način zaznavala slovanski svet kot nekaj negativnega. Dobro poznamo tudi napetosti med samo skupnostjo, res so potiskali slovenščino na rob. Nekateri izmed nas smo jo /slovenščino, op. a./ celo doživljali kot nekaj, kar gre skrivati, kot omalovažujočo lastnost.)

223: Ai tempi dei miei genitori, mio papà che ha avuto quell'esperienza in collegio, lì è subentrata la vergogna. Già un pò superata da me e mia sorella. Noi due non siamo di lingua materna slovena /.../. Io e mio sorella con $i$ discorsi di mia mamma e mio papà, chi siamo, dove siamo, frequentiamo quello, perchè ci fa bene ... non avevamo questa vergogna. /.../ Vedo nella generazione dei miei figli non c'è la vergogna, ma è subentrato l'orgoglio. Questa è una gran cosa /.../. (Za časa mojih staršev je imel moj oče tisto izkušnjo $v$ zavodu, tam je nastopila sramota. Sestra in jaz sva jo že malce premostili. Medve nisva slovenskega maternega jezika /.../,jaz in moja sestra 
s pridigami moje mame in mojega očeta, kdo smo, kje smo, obiskujemo tisto, ker je koristno ... nisva imeli te sramote /.../. Vidim, da $v$ generaciji mojih otrok ni sramote, nastopil je ponos. To pa je res pozitivno /.../.)

223: E poi il fatto che i miei genitori hanno avuto sempre questo pudore a parlarmi in dialetto /.../. (In tudi dejstvo, da so se moji starši vedno sramovali govoriti z mano $v$ narečju /.../.)

211: Infatti è una delle cose che rinfaccio ai miei sinceramente, che non ce l'hanno insegnato /lo sloveno, op. au./. (Namrečje to nekaj, kar očitam svojim staršem, odkritosrčno, da nas niso naučili /slovenščine, op. a./).

Danes se je med nekaterimi starši razvila ozaveščenost o prednosti zgodnje dvojezičnosti. Zato se pogosto dogaja, da tudi enojezični starši izberejo dvojezično šolanje, da bi se njihov otrok razvil v dvojezičnega govorca. Pri starših italijanske narodnosti smo preverjali, kateri dejavniki vplivajo na to izbiro. Ali je pri izbiri za dvojezično šolanje pomembno, da je slovenščina jezik območja in sosednje Slovenije, ali pa starši v tem primeru izhajajo zgolj iz želje po dvojezičnem šolanju in je bila to najenostavnejša možnost $\mathrm{v}$ danem okolju?

210: /.../ io ho sempre visto la possibilità della scuola bilingue non tanto legata all'uso della lingua di questa zona, quanto in generale il bilinguismo come un'opportunità in più, ginnastica per la mente. Te la dà qualsiasi lingua tu studi, comunque devi cambiare la tua testa da un momento all'altro $e$ comunque è utile in generale. Rende più facile il ragionamento, ti rende più pronto, più pratico. Se fosse stata la scuola bilingue di russo l'avrei mandato lo stesso, indipendentemente dalla lingua. Ovvio che lo fai ancora più volentieri, perché lì ci sono nato, vissuto qua, abbiamo un'origine chiaramente comune con chi sta al di là del confine, perché perdere questa possibilità. Io non ho avuto la stessa occasione, quando avevo l'età questa era una scuola privata e non potevamo accedere, per cui sì è stata una scelta automatica. (/.../ vedno sem razumela možnost dvojezičnega šolanja bolj kot nekaj, kar je 
povezano z rabo jezika na tem območju, raje kot dodatno možnost, telovadbo za možgane. Tako možnost lahko nudi učenje katerega koli jezika, moraš vsekakor preklapljati možgane vsak trenutek in je vsekakor nasploh koristno. Olajša razmišljanje, te bolje pripravi in izuri. Če bi bila dvojezična šola ruščine, bi ga vsekakor vpisal, ne glede na jezik. Seveda to narediš s še večjim veseljem, ker si se tam rodil, živel tukaj, imamo nedvomno skupen izvor s tistimi, ki so na drugi strani meje, zakaj zamuditi tako priložnost. Jaz nisem imel take možnosti, ko sem bil majhen, to je bila privatna šola in se nismo mogli vpisati, zato je bila samodejna odločitev.)

211: Perché per me era assolutamente un'opportunità. Fosse stato, come dicono tutti, se era l'inglese, però visto che inglese non era, lo sloveno, benissimo, si impara comunque una cosa in più. (Ker zame je bila nedvomno priložnost. Če bi bila, kot vsi pravijo, če bi bila angleščina, ampak angleščina ni bila na voljo, slovenščina, zelo dobro, se vsekakor naučimo nečesa več.)

214: C'era in primis la possibilità di potergli dare, di offrire un qualche cosa che a lui sarebbe servito più avanti, un'opportunità. E secondo era anche un'esigenza un pò a livello organizzativo. (Najprej je bila to možnost, da mu lahko damo, nudimo nekaj, kar mu bo prišlo prav $v$ prihodnosti, neko priložnost. Potem pa je bila to tudi potreba iz organizacijskih razlogov.).

Sicer pa so starši izrazili enotno stališče, da je šola znana v širšem prostoru zaradi kakovosti, močne vpetosti v prostor, dobrega učnega osebja itd.

216: Sì, certo, perché /gli altri genitori, op.au./ riconoscono da subito l'importanza della lingua in più, e sentono in giro che c'è grande soddisfazione nei confronti di questa scuola, perché ha una marcia in più. (Ja, seveda, ker /ostali starši, op. a./ hitro prepoznajo pomembnost dodatnega jezika in slišijo, da je naokoli veliko zadovoljstva s to šolo, ker nudi dodatne vrednosti.)

216: mi è sempre piaciuta, loro investono molto sul territorio, raccontano molto, portano i bambini, vivono molto il territorio, non solo con attività didattiche presentate a scuola, ma proprio con gite, andando da persone che 
raccontano come era una volta. Per conoscere la cultura. (vedno mi je bila všeč, vlagajo veliko $v$ to okolje, pripovedujejo veliko, peljejo otroke naokoli, zelo doživljajo okolje, ne le z didaktičnimi aktivnostmi, ki jih predstavijo $v$ šoli, ampak prav z izleti, z obiski pri ljudeh, ki pripovedujejo, kako je bilo nekoč. Da bi se naučili kulture.).

217: Ostale šole niso tako kvalitetne. Ampak predvsem je ta tudi za jezik.

223: Io dico sempre, più che una scuola quella è un centro culturale, perchè tutta questa cultura che ruota attorno alla scuola sono come dei pilastri che sorreggono la scuola. Sono dei pilastri molto importanti, perchè portano la lingua fuori dal libro, la portano nella quotidianità. (Vedno pravim, bolj kot šola je to kulturno središče, ker vsa ta kultura, ki se vrti okoli šole, so kot stebri, ki podpirajo šolo. So zelo pomembni stebri, ker nosijo jezik iz knjig, prinašajo gav vsakdanjost.)

Tisti starši, ki imajo slovenske korenine, se zavedajo, da je šola mlajšim rodovom posredovala tudi zavest o pomenu slovenščine kot jezika območja in kulturne dediščine Beneške Slovenije. Med njimi obstaja percepcija, da so mlade generacije ponosne na svoje znanje slovenščine, ki ga vrednotijo visoko.

218: Vedo che i ragazzi che hanno frequentato quella scuola hanno anche percepito l'importanza, la ricchezza di un certo mondo. /.../ vedere giovani così danno speranza. /.../ Diciamo che li vedi che vivono volentieri queste esperienze e si sentono arricchiti /.../. (Opažam, da so otroci, ki so obiskovali tisto šolo, tudi zaznali pomembnost, bogastvo nekega sveta. /.../ Taka mladina nam vliva upanje. /.../ Recimo, da se vidi, kako rade volje doživljajo take izkušnje in kako jih bogatijo /.../.)

223: Mi creda, adesso li vedo questi giovani, che organizzano il pust, ecc. tentano in tutti i modi di parlare il dialetto, dicendo strafalcioni, ci tentano in tutte le maniere. (Verjemite mi, zdaj vidim to mladino, ko prireja pust ipd., ki skuša na vse načine govoriti $v$ narečju, strelja kozle, ampak poskuša na vse načine.) 
209: Sada, ki so veliki - kako se reče - "apprezzano" /cenijo, op. a./ to znanje. Je pa raba slovenščine $\mathrm{v}$ prostoru zelo omejena na šolsko okolje, šolske in obšolske dejavnosti v slovenskih društvih. V družinah je njena raba bolj skromna. Tudi med starši, ki imajo slovenske korenine, se pogosto dogaja, da slovenščina ni jezik, v katerem se pogovarjajo s svojimi otroki. Razlogi so različni. Predvsem gre za percepcijo staršev, da v slovenščini niso dovolj jezikovno kompetentni, zato $\mathrm{v}$ večini govornih položajev uporabljajo italijanščino.

223: Io con i miei figli non parlo in dialetto /sloveno, op.a./ e i miei genitori fanno fatica. /.../ Perchè non me la sento, perchè magari penso di sbagliare ad esprimermi. (S svojimi otroki ne govorim v narečju /slovenskem, op. a./ in moji starši ga govorijo s težavo. /.../ Ker si ne upam, ker pravzaprav mislim, da delam napake pri izražanju.)

222: Nella comunicazione con il figlio usiamo l'italiano. Lo sloveno no, perchè il nostro è dialetto e lui ci corregge. Soprattutto la pronuncia, perchè magari la parola è anche corretta, ma la pronuncia no. (Pri sporazumevanju z otrokom uporabljamo italijanščino. Slovenščine ne uporabljamo, ker pri nas gre za narečje, in on nas potem popravlja /ker pozna standardno slovenščino , op.a./. Predvsem izgovarjavo, ker je beseda verjetno pravilna, ampak izgovarjava ne.)

218: Doma govorimo bolj italijansko, je žal.

\section{PRVI ZAKLJUČKI}

Prikazani podatki omogočajo nekaj prvih zaključkov. Pri generaciji staršev otrok, ki obiskujejo dvojezično šolo v Špetru in se vsaj delno istovetijo tudi s slovensko narodno skupnostjo oz. so imeli slovenske prednike, je mogoče opaziti določeno mero zagrenjenosti, da so odraščali v obdobju, ki slovenščini ni bilo naklonjeno. Med tistimi, ki izhajajo iz slovenskih družin, je prisotno prepričanje, da so bili prikrajšani za možnost šolanja v slovenščini, kar je imelo 
ključne posledice na njihov jezikovni razvoj, današnje govorne navade v družini ter sporazumevalne zmožnosti v slovenskem jeziku. Medgeneracijski prenos jezika je pogosto zastal z začetkom šolanja oz. vstopom v vrtec, ki je prinesel prehod na italijanski jezik. Starši so nam v intervjujih povedali, da so zaznali, da so italijanske državne šole bolj ali manj prikrito razvile odklonilen donos do slovenskega jezika in težnjo po jezikovni asimilaciji. Izsledili smo primere družin, $\mathrm{v}$ katerih so do vpisa otroka $\mathrm{v}$ vrtec uporabljali slovenščino kot pogovorni jezik v družini, otrok je začel razvijati govor v slovenščini vse do vstopa v vrtec, ko so po priporočilu učnega osebja spremenili jezikovni kod. Zaradi teh dinamik je zmanjkala vmesna generacija slovenskih govorcev oz. suverenih slovenskih govorcev. Iz pogovorov je namreč možno izluščiti, da ti starši še razumejo slovenščino in slovensko narečje, saj so bili pasivno izpostavljeni slovenskemu jeziku, zlasti s strani starih staršev, nimajo pa razvitih govornih kompetenc. Za nekatere je bilo to veliko breme in so se kot odrasli začeli učiti slovenščino. Ti danes kot pogovorni jezik s svojimi otroki uporabljajo tudi slovenščino. Drugi pa se v rabi slovenščine ne počutijo suverene in zato tudi v domačem okolju uporabljajo italijanski jezik. Vseeno so pri njih prisotni elementi slovenske identitete, tudi če slovenščina ni več njihov primarni jezik. Podobno ugotavlja tudi Pertot (2007), ko navaja, da se pogosto pojavljajo kompleksnejše oblike večplastnih identitet, ob katerih se poraja vprašanje, ali so še neizogibno povezane z znanjem in rabo manjšinskega jezika. Za svoje otroke so ti starši brez dvomov izbrali dvojezično šolanje. V teh primerih ne moremo govoriti o jezikovni asimilaciji staršev, ker se je ohranil del slovenske identitete in kulture, za naslednje generacije pa gre občutiti pri starših poskus jezikovne revitalizacije: otroke so vpisali v dvojezično šolo, obiskujejo obšolske dejavnosti v slovenskem okolju, vključujejo se v slovensko družbeno-kulturno okolje. Podobno kot na Tržaškem in Goriškem ti starši pričakujejo, da bo šola pri otrocih spodbudila medgeneracijski prenos jezika, kulture ter identitete (Pertot 2013). Šoli priznavajo, da je močno povezana z območjem in da $\mathrm{v}$ mladih razvija občutek za kulturno dediščino Beneške 
Slovenije. Pri mladih, ki so zaključili dvojezično šolo, opažajo določeno zavedanje pomena slovenskega jezika, kulture in običajev. Pri mladih generacijah občutijo tudi ponos, ki med prejšnjimi generacijami ni bil tako samoumeven oz. se je v nekaterih primerih sprevrgel celo v njegovo nasprotje: občutek sramu.

V danih razmerah se postavlja vprašanje, ali bo dvojezični šoli s podporo družine in drugih krajevnih nosilcev interesov (slovenskih institucij) uspelo spremeniti trend in pri mlajših generacijah vzbuditi doslednejšo rabo slovenščine v vsakdanjih sporazumevalnih praksah. Zbrani podatki kažejo, da je slovenščina na dvojezični šoli zelo omejena na učni proces in da učenci oz. dijaki med sabo večinoma uporabljajo italijanščino, razen med poukom slovenščine. Eden od razlogov za tak trend je gotovo tudi ta, da dvojezični vrtec in šolo obiskuje veliko učencev, ki ne izhajajo iz slovenskih družin, kar pomeni, da se ob vstopu v šolo oz. vrtec otroci med sabo po jezikovni zmožnosti v slovenščini zelo razlikujejo (Pertot 2013). Italijanščino po večini uporabljajo tudi v obšolskih in prostočasnih dejavnostih ter med druženjem z vrstniki. Sicer iz intervjujev izhaja, da se starši z danim položajem slovenščine pretirano ne obremenjujejo, saj nismo zaznali pričakovanja, da bi si slovenščina utirala pot v vsakdanje sporazumevalne prakse. Svoje otroke imajo za dvojezične, kljub temu da je izpostavljenost obema jezikoma izrazito neuravnotežena, kar gotovo vpliva na razvoj jezikovnih veščin in sporazumevalnih spretnosti. Kot ugotavlja tudi Grgičeva (2017), se lahko strinjamo s hipotezo, da so otroci načeloma dvojezični, vendar pa je njihov primarni jezik le večinski jezik, manjšinski jezik pa je izrazito oslabljen.

Dvojezično šolanje je za Beneško Slovenijo pomemben dosežek, vendar to še ni zadosten pogoj za ohranjanje ali oživitev medgeneracijskega prenosa jezika. Iz intervjujev izhaja, da starši prepuščajo ustvarjanje ostalih okoliščin, v katerih se razvija znanje slovenskega jezika, šoli in obšolskim dejavnostim. Potrebni so še drugi ukrepi jezikovnega načrtovanja in jezikovne politike, predvsem spodbujanje rabe slovenščine $\mathrm{v}$ družinah ter raznih organizacijskih enotah 
civilne družbe, kar bi obenem nudilo tudi možnost večje rabe slovenščine po zaključku dvojezične šole. Kljub prizadevanjem ni enostavno prebiti ustaljene prevlade italijanskega jezika in posledično večje izpostavljenosti prebivalstva italijanščini. Institucionalno šolsko ponudbo izobraževanja $\mathrm{v}$ slovenščini dopolnjujejo pobude posameznih društev, ki mladim ponujajo dejavnosti za prosti čas, odraslim pa tečaje slovenskega jezika (Gruden 2009). Krajevna društva razvijajo kulturne in jezikovne dejavnosti, ki so namenjene zlasti mladim. V Beneški Sloveniji so še posebej pomembni glasba, gledališče, razstave, rekreacijske in športne dejavnosti (Cernetig in Negro 2009).

Med nekdanjimi učenci in dijaki dvojezične šole, ki imajo slovenske prednike, starši opažajo zavest o slovenski identiteti, ki jo ponosno ohranjajo in razvijajo. Tudi Zuljan Kumar (2016: 11) ugotavlja, da je danes zaradi ugodnejših družbenih razmer izražanje slovenske identitete postalo bolj odprto tudi v italijanskem prostoru in ni omejeno samo na življenje znotraj slovenske skupnosti. Intervjuvani starši slovenske narodnosti menijo, da se mlajše generacije, ki so obiskovale dvojezično šolo v Špetru, bolj zavedajo svoje pripadnosti slovenstvu, saj so se s problematiko identitete in državljanstva seznanile ter jo ozavestile tudi $\mathrm{v}$ šoli. $\mathrm{V}$ njihovi percepciji $\mathrm{v}$ primerjavi $\mathrm{s}$ preteklostjo identiteta danes ni močnejša, izraža pa se bolj odkrito. Mladi vrstniki danes sprejemajo to, da je nekdo Slovenec, kot nekaj povsem normalnega. Obenem iz pogovorov izhaja, da mlajši pri svojih italijanskih vrstnikih opažajo tudi določeno spoštovanje do slovenskih vrstnikov in jezika.

Ob tem gre poudariti, da se ti procesi razvijajo v okolju, ki je vse bolj odprto in naklonjeno slovenščini ter dvojezičnosti. Spremenjena stališča do slovenščine in Slovencev ter do zgodnje dvojezičnosti nasploh so privedla do tega, da se vse več staršev, ki nimajo slovenske identitete, odloča za dvojezično šolo. Razlogov, zaradi katerih se neslovensko govoreči starši odločajo za slovenski vrtec ali šolo, je lahko več. Nekateri se odločajo naključno (prijatelji, udobnost, lega), drugi pa premišljeno (Bogatec in Bufon 1996; Colja 2001; Pertot 2004). Med slednje sodijo tisti, ki želijo oživiti slovenske korenine svojih prednikov, in tisti, ki 
hočejo nuditi otroku več možnosti (Pertot 2013), saj so nekateri prepričani, da je vsak dodatni tuji jezik ter še posebej jezik sosednje države lahko koristen za študij in/ali za delo.

Italijanski starši so izbrali dvojezično šolo, ker v današnjih časih zgodnja dvojezičnost vzbuja med starši določene apetite, doživljajo jo kot dodatno možnost za boljšo prihodnost otroka. Slovenščino pa so izbrali po sili razmer, ker je bila najugodnejša rešitev za željo po dvojezičnem šolanju. Mestoma pa tudi zato, ker je jezik bližnje Slovenije. Po mnenju teh staršev je pomembno poznati jezik soseda, ne zaznajo pa slovenščine tudi kot jezika tega prostora in raba slovenščine $\mathrm{v}$ tem obmejnem prostoru jim ni tako relevantna. Verjetno tudi zato, ker slovenščina v Beneški Sloveniji ni dejansko vsestransko prisotna v okolju in je večinsko prebivalstvo ne dojema kot take (glej Grgič 2017).

Lahko torej zaključimo, da pričakovanja slovenskih in italijanskih staršev do dvojezične šole niso povsem skladna, saj slednji vidijo dvojezično šolo kot prostor za usvajanje slovenskega jezika oz. dvojezično šolanje, ne pa kot posrednika slovenske identitete in kulture (Pertot 2013).

Z nadaljnjim raziskovalnim delom želimo preučiti, ali je med populacijo učencev špetrske šole, ki imajo slovenske korenine in prednike, proces jezikovne deasimilacije možen in v kakšnih razmerah. Prav tako želimo preučiti, kateri so ključni dejavniki, ki vplivajo na prenos oz. pomanjkanje prenosa jezika. Analiza deasimilacije na tem območju predstavlja novo raziskovalno perspektivo. Proces deasimilacije je pomemben tudi za širjenje kroga potencialnih govorcev slovenščine. Raziskati želimo tudi, kakšno vlogo imajo pri tem družina, šola in širše družbeno okolje.

Glede na zastavljeno raziskovalno hipotezo, da v Beneški Sloveniji obstajajo ugodne okoliščine za jezikovno revitalizacijo in deasimilacijo mlajših generacij, podatki nakazujejo, da se vzpostavljajo okoliščine za deasimilacijo mlajših generacij, težje pa je vzpostaviti razmere za jezikovo revitalizacijo. Pri procesu 
asimilacije se socializacijskim dejavnikom ${ }^{7}$ spremeni etnični »predznak « (Susič 2003), to pa privede do tega, da posameznik postopoma izgubi čut pripadnosti. Ta proces se je sprožil pri generaciji staršev, ki ni imela možnosti razvijati določenih pomembnih socializacijskih dejavnikov s slovenskim »predznakom « (od šole do obšolskih dejavnosti), je pa treba dodati, da se proces asimilacije vendarle ni vedno zaključil, saj nekateri v raziskavo vključeni starši še občutijo del slovenske identitete. Pri naslednji generaciji pa lahko vsaj delno govorimo o deasimilaciji, ker so se nekateri etnični »predznaki« socializacijskih dejavnikov spremenili v prid slovenščini.

Za jezikovno revitalizacijo je največjo pridobitev pomenila prav možnost dvojezičnega šolanja. S tem se širi krog potencialnih govorcev in se zvišuje družbeni ugled jezika. Šibko točko pa predstavlja predvsem omejena raba slovenščine. Potrebno je okrepiti prizadevanja in razvijati ustrezno jezikovno politiko za ohranitev in krepitev slovenščine kot jezika primarne socializacije. S tem se širi baza aktivnih govorcev in spodbuja aktivna raba jezika, to pa sta dva ključna pogoja za jezikovno revitalizacijo (Fishman 1991; 2001).

\section{LITERATURA}

Bogatec, N. (2016a): Izobraževanje v slovenskem jeziku v Italiji. V M. Tavčar (ur.): Koledar 2017: 291-300. Gorica: Mohorjeva družba.

Bogatec, N. (2016b): Istruzione, formazione e ricerca in lignua slovena in Italia. V N. Bogatec in Z. Vidau (ur.): Una comunità nel cuore dell'Europa: 11-127. Rim: Carocci editore.

Bogatec, N. (2015a): Izobraževanje v slovenskem jeziku v Italiji. V M. Tavčar (ur.): Koledar 2016: 267-276. Gorica: Mohorjeva družba.

Bogatec, N. (2015b): Šolanje v slovenskem jeziku v Italiji. Razprave in

7 Socializacijski dejavniki so v bistvu posamezniki, skupine in inštitucije, s katerimi današnji človek integrira v teku celotne življenjske dobe (Susič 2003: 246). 
gradivo, 74: 5-21.

Bogatec, N. (2012a): Izobraževanje v slovenskem jeziku v Italiji. V M. Tavčar (ur.): Koledar 2013: 278-284. Gorica: Mohorjeva družba.

Bogatec, N. (2012b): Projekt šola 2011. Dostopno prek: http://www.slori.org/detail.php?lang=slo\&t=progetti\&id=105 (27. 10. 2017).

Bogatec, N. (2011): Izobraževanje v slovenskem jeziku v Italiji. V M. Kafol (ur.): Jadranski koledar 2012: izobraževanje, biografija: 4-19. Gorica: Grafica Goriziana.

Bratina, D., in Sussi, E. (1988): Il segno come affermazione e negazione: simboli e identità etnica. V Suppletmento al bollettino n.2, Presenza e contributo della cultura slovena a Trieste: $23-32$. Trieste: IRRSAEAssociazione culturale regionale »Gruppo 85«.

Bogatec, N., in Bufon, N. (1996): Slovenske šole V Tržaški in Goriški pokrajini: vrtci in osnoune šole. Trst: Slori.

Cernetig, M., in Negro, L. (ur.) (2009): Mi smo tu. Passian di Prato: Inštitut za slovensko kulturo, SLORI, Univerza v Vidmu.

Colja, T. (2001): Trasmissione culturale e identitaria nei matrimoni misti: analisi di una realtà concreta. Trst: SLORI.

Fishman, J. A. (ur.) (2001): Can treathened languages be saved? Reversing language shift, revisited: a 21st century perspective. Clevedon: Multilingual Matters.

Fishman, J. A. (1991): Reversing language Ahift: Theory and practice of assistance to threatened lanugaes. Clevedon: Multilingual Matters.

Gliha Komac, N. (2009): Slovenščina med jeziki Kanalske Doline. Fakulteta za družbene vede Univerze v Ljubljani; Slovensko središče Planika Ukve, SLORI Trst. 
Grgič, M. (2017): Italijansko-slovenski jezikovni stik: med ideologijo in pragmatiko. Jezik in slovstvo, 61 (1): 89-98.

Gruden, Ž. (2009): Slovenščina na poti v šolo. V M. Cernetig in L. Negro (ur.): Mi smo tu: 32-33. Passian di Prato: Inštitut za slovensko kulturo, SLORI, Univerza v Vidmu.

Gruden, Ž. (1997): Nekaj opažanj o jezikovnih vidikih raziskave. V D. Sedmak (ur.): Podoba našega otroka v Benečiji: 39-45. Gorica: SLORI.

Jagodic, D., Kaučič Baša, M., in Dapit, R. (2016): Situazione linguistica degli sloveni in Italia. V N. Bogatec in Z. Vidau (ur.): Una comunità nel cuore dell'Europa: 71-95. Rim: Carocci editore.

Maver, M. (2015): Šola, družina in zunajšolske dejavnosti. Gorica: Združenje slovenskih športnih društev v Italiji.

Mezgec, M. (2015): Raziskava o jezikovni pokrajini na naselitvenem območju slovenske skupnosti $v$ Italiji: Raziskovalno poročilo. Trst: SLORI.

Mezgec, M. (2004): Možnosti vseživljenjskega izobraževanja v manjšinskih jezikih Evropske unije. Annales, Series Historia et Sociologia, 14 (1): 151-170.

Pertot, S. (2013): Kaj je to za ena šola: slovenska ali dvojezična? Predstave staršev o ciljih in delovanju šol s slovenskim učnim jezikom v Italiji. V R. Dapit in M. Bidovec (ur.): Večjezičnost in izobraževanje: izkušnje, rezultati in izzivi $v$ prostoru med Italijo in Slovenijo: 151-177. Udine: Università di Udine - Centro Internazionale sul Plurilinguismo.

Pertot, S. (2007): V imenu očeta: medgeneracijski prenos slovenskega jezika in identitete po moški liniji. V M. Košuta (ur.): Živeti mejo: 255-266. Trst; Ljubljana: Slavistično društvo Slovenije.

Pertot, S. (2004): Otroci govorite slovensko? Vpliv narodnostno mešane družine na jezikovni razvoj otroka. V S. Pertot (ur.): Otroci in starši na 
poti do slovenščine: $13-52$. Trst: SLORI.

Stranj, P. (1992): La comunità sommersa: Sloveni dalla A alla Z. Trst: Est.

Susič, E. (2003): Socializacija, asimilacija in pravni položaj. Acta histriae, 2003 (2): $237-254$.

Susič , E. (1998): Slovenci v Italiji: jezik in identiteta. V I. Štrukelj (ur.): Jezik za danes in jutri: Zbornik referatov na II. kongresu $v$ Ljubljani (8.-10. oktober 1998): 112-122. Nova Gorica: Grafika Soča.

Vidau, Z. (2016): Quadro giuridico di tutela della comunità nazionale slovena in Italia. V N. Bogatec in Z. Vidau (ur.): Una comunità nel cuore dell'Europa: 53-59. Rim: Carocci editore.

Vogrinc, J. (2008): Kvalitativno raziskovanje na pedagoškem področju. Ljubljana: Pedagoška fakulteta.

Zuljan Kumar, D. (2016): Narodna identiteta pri Beneških Slovencih in Furlanih danes. Jezik in slovstvo, 61 (2): 7-18. 


\section{SLOVENE IN BENEČIJA AND THE ROLE OF THE BILINGUAL SCHOOL IN SAN PIETRO AL NATISONE/ŠPETER IN THE INTERGENERATIONAL TRANSMISSION OF LANGUAGE FROM THE PARENTS' STANDPOINT}

The paper presents the first part of the study within the research project Opportunities and possibilities of preservation and revitalization of the Slovene language among the Slovene minority community in the neighbouring states, which aims to analyse the situation in Benečija. In the era of global processes, European integrational processes, more favourable and sound legal bases (protection laws) and especially because of bilingual schooling, we assume that in the province of Udine there are the premises for linguistic revitalisation and de-assimilation of younger generations, including the intergenerational transmission of language and/or study of Slovene among the generations where this transmission has been interrupted. The paper introduces the first results of the study which aims to analyse the intergenerational transmission of the Slovene language, the reasons why parents have chosen bilingual schools and their expectations about bilingual schooling. A combination of qualitative and quantitative data has been analysed. Available data concerning Slovenes in Italy has been reviewed. Special stress has been put on data regarding the areas of Udine/Videm and Benečija. In the empirical part, qualitative data has been collected with interviews among parents of children attending the bilingual school in the school year 2016/17. On the basis of the answers, it can be presumed that in the previous generation the intergenerational transmission of Slovene language was often interrupted as schooling started, more exactly nursery school, which marked the transition to Italian. Consequently, bilingual schooling represents an important achievement for the Slovene population of the province of Udine. However, bilingual schooling itself cannot guarantee language preservation and revitalisation. There is the need of more support by means of language planning and policies. It has to be highlighted that all these processes are going on in an environment that is increasingly open and favourable for the Slovene language and bilingualism.

Keywords: Slovene minority, bilingual education, de-assimilation, intergenerational language transmission 
To delo je ponujeno pod licenco Creative Commons: Priznanje avtorstvaDeljenje pod enakimi pogoji 4.o Mednarodna.

This work is licensed under the Creative Commons Attribution-ShareAlike 4.0 International.

https://creativecommons.org/licenses/by-sa/4.0/

(c) (i) () 